\title{
Productivity, social expenditure and income distribution in Latin America
}

\author{
Produtividade, gasto social e distribuição \\ de renda na América Latina
}

\author{
MARIO CIMOLI \\ GABRIEL PORCILE \\ ANTONIO MARTINS NETO \\ FERNANDO SOSSDORF"
}

\begin{abstract}
RESUMO: Este artigo discute o papel das instituições e das mudanças estruturais sobre a desigualdade de renda. Argumenta-se que enquanto o gasto social e a transferência de renda são fatores cruciais à melhora da distribuição de renda, a continuidade desse processo depende de mudanças estruturais. A importância relativa dessas variáveis em diferentes países é avaliada e uma tipologia é sugerida. Argumenta-se que os países mais igualitários combinam instituições em favor da redistribuição e estruturas produtivas intensivas em conhecimento. Na América Latina, instituições e estrutura produtiva falham em promover a igualdade, o que explica seus elevados níveis de desigualdade. Baseado em uma amostra de países em desenvolvimento e desenvolvidos para o período 1990-2010, este artigo apresenta evidência empírica que suporta este argumento. Instituições que favorecem a distribuição são medidas pelo gasto social como uma porcentagem do PIB, enquanto o papel da estrutura produtiva é medido por indicadores de intensidade tecnológica e pela evolução da produtividade do trabalho. A intensidade tecnológica, por sua vez, é capturada por dois indicadores: o Índice de Complexidade Econômica e o Índice de Intensidade Tecnológica da CEPAL.

PALAVRAS-CHAVE: Distribuição de renda; mudança estrutural; gasto social.
\end{abstract}

ABSTRACT: This paper discusses the role of institutions and structural change in shaping income inequality. It is argued that while social expenditure and direct redistribution are crucial for improving income distribution, sustainable equality requires structural change. The relative importance of these variables in different countries is analyzed and a typology suggested. It is argued that the most equal countries in the world combine strong institutions in favor of redistribution and knowledge-intensive production structures that sustain growth and employment in the long run. Both institutions and the production structure in

\footnotetext{
* DPPM, Economic Commission for Latin America and the Caribbean (ECLAC) and University of Venice, e-mail: Mario.Cimoli@cepal.org; DPPM, ECLAC and Federal University of Parana, e-mail:Jose.Porcile@ Cepal.org; DPPM, ECLAC, E-mail:antonio.martins@un.org; DPPM, ECLAC, email: Fernando.Sossdorf@ Cepal.org. Submitted: 23/December/2015; Approved: 23/January/2017.
} 
Latin America fail to foster equality and this explains its extremely high levels of inequality. The paper presents empirical evidence that supports this view, based on a sample of developed and developing countries for the period 1990-2010. Institutions for redistribution are captured through social expenditures as a percentage of GDP, while the role of structural change is captured by indicators of the technological intensity of production and the evolution of labor productivity. The technological intensity of the production structure is proxied through two indicators, the Economic Complexity Index and the ECLAC Index of Technological Intensity.

KEYWORDS: Income distribution; structural change; social expenditure.

JEL Classification: D30; H52; O33; O54.

\section{INTRODUCTION}

This paper discusses the role of institutions and structural change in income distribution. It is argued that social expenditure and direct redistribution are crucial for reducing inequality, but there are limits to the degree of equality that could be attained solely through social expenditure. Inequality cannot be reduced in developing economies without a dramatic reduction of underemployment and informality. This in turn requires structural change in favor of higher-productivity activities and jobs.

The topic is of great relevance for Latin America, which is one the most unequal regions in the world (the other being Sub-Saharan Africa) (ECLAC, 2016). Latin America has gone through periods of rapid economic growth in the 1960s and 1970s, stagnation in the 1980s, and rather slow economic growth in the 1990s. In all these phases, income distribution remained highly unequal. With the commodity boom beginning in 2004, economic growth accelerated and for the first time in the post-Second World War period such a recovery was accompanied by a fall in inequality. This is true when inequality is measured by the Gini index, which only captures a dimension of inequality, basically that associated with differences in wages. The functional distribution of income, on the other hand, has not improved. The wage share in GDP remained more or less at the same figures in most Latin American countries in the 2000s (see ECLAC, 2014; for a longer term perspective, see Bértola and Ocampo, 2012). The improvement in income distribution after 2005 was spurred by higher formal employment, higher minimum wages, and higher levels of transfers and social expenditure.

However, at the same time, growth has become more dependent on exports of commodities to the Asian markets - and therefore highly vulnerable to changes in international conditions (particularly to a slowdown of growth in China) ${ }^{1}$. Productivity growth has been meager, which poses doubts about the ability of LA to continue improving income distribution in the future. If productivity does not

\footnotetext{
${ }^{1}$ The slowdown of international demand has become more apparent since mid-2013 (ECLAC, 2014).
} 
grow steadily, the potential to increase social expenditure to fight poverty and encourage social inclusion will find a ceiling. Slow productivity growth compromises competitiveness, which in turn compromises growth and the creation of formal employments. It is therefore necessary to consider trends in both social expenditure and productivity together in order to assess whether recent improvements in income distribution are sustainable, particularly if the international economy losses its momentum. The paper presents empirical evidence that supports this view, based on a sample of developed and developing countries for the period 1990-2010. Institutions for redistribution are captured through social expenditures as a percentage of GDP, while the role of structural change is captured by indicators of the technological intensity of production and the evolution of labor productivity. The technological intensity of the production structure is proxied through two indicators, the Economic Complexity Index and the ECLAC Index of Technological Intensity.

The paper is organized in six sections plus this introduction. Second section discusses the stylized facts about income distribution, productivity and institutions in a sample of countries; third section addresses the role of institutions in income distribution; fourth section discusses the importance of the production structure; fifth section suggests a typology that emerges from combining the production structure and the institutional setting; sixth section articulates the different parts in a simple, Balance-of-Payments constrained model. A final section concludes.

\section{THE PRODUCTION STRUCTURE, INSTITUTIONS AND INCOME DISTRIBUTION}

This paper focuses on two determinants of income distribution, namely the production structure (and its link with productivity and employment) and redistributive institutions (social expenditure and direct redistribution). As regards the production structure, a diversified economic structure with a large share of knowledge-intensive activities is necessary for equality because it sustains growth and employment (see Rodrik and McMillan, 2011; Cimoli and Porcile, 2014) and provides the income basis for taxes and transfers. In turn, redistributive institutions are necessary to ensure that taxes and transfers favor workers at the bottom of the income distribution and correct the negative impact on equality of skill-biased technical change. The combination of different production structures and institutional settings gives rise to different outcomes in terms of equality (measured in this paper by the Gini index).

Graph 1 puts both dimensions together to produce a typology of patterns of income distribution. The variable labor productivity is used as a proxy for the diversification and knowledge-intensity (DKI) of the production structure ${ }^{2}$; the level of social expenditure as a percentage of GDP is used as a proxy for the strength of the

\footnotetext{
2 Other proxies are used below. The use of different proxies do not change the countries' position in the matrix.
} 
institutions favoring equality (or government effort to attain higher equality) ${ }^{3}$. Plotting the two proxies generates a distribution of points in which the Northeast quadrant represents countries with a high DKI production structure and strong commitment to equality; the Southwest quadrant comprises countries with simple structures which in addition exhibit low preference for equality; the Southeast quadrant includes countries whose preference for equality is high, but not supported by a DKI production structure; and finally the Northwest quadrant includes countries that stress structural change and competitiveness, but which are less sensitive to its distributive impacts. The size of the circle that marks the position of each country in Graph 1 represents the Gini coefficient - the larger is the circle, the more unequal the country; the figure besides the circle is the Gini. The straight lines show the co-evolution of productivity and social expenditure as a percentage of GDP between 1990 and 2010.

Graph 1: Social expenditures,

labor productivity and income distribution

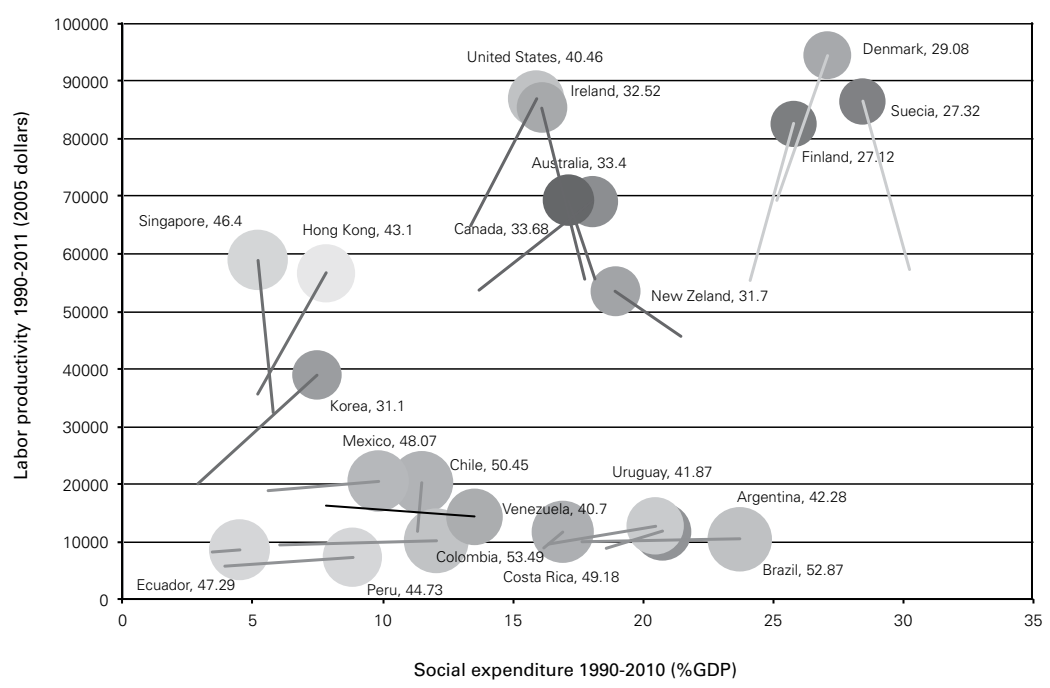

Bubble size represents income distribution measured by the Gini index of 2010.

Sources: INDSTAT4 2013, UNIDO; World Development Indicators, World Bank; COMTRADE; Laborstat, ILO; CEPALSTAT; OECD.

The Northeast quadrant corresponds to the Scandinavian countries, which display the best indicators of income distribution (the smallest circles, lowest Gini) and among the highest levels of labor productivity in the world. The production

\footnotetext{
${ }^{3}$ Social expenditure includes the expenditures in education, health, social security and welfare, housing and other (water and sewer). This variable is used as a proxy of the government effort to reduce inequality. However, it is an imperfect measure, as some of this social expenditure has a small redistributive impact (as it is the case of social security expenditures in Brazil).
} 
structure of these countries is diversified and technology-intensive, endowed with highly sophisticated capabilities. An encompassing welfare state gives rise to a high share of social expenditure as a percentage of GDP. The Northwest quadrant represents developed countries whose production structures display very high levels of technological intensity, but in which equality is not a core concern in society. High relative productivity levels are accompanied in these countries by higher inequality than in the Nordic group.

Most Latin American countries, meanwhile, are in the Southwest quadrant. In this box there are countries whose growth and distribution dynamics are marked by high inequality and the dependency of exports on a small set of commodities. Public expenditure in social welfare is in general very small. The exemptions are Argentina, Uruguay and Brazil, where social expenditure is relatively high (Southeast quadrant). The last three countries show levels of social expenditure similar or even higher than many OECD countries, but they are nevertheless more unequal. This occurs in part because a significant share of total social expenditure goes to pay pensions, which in Latin America do not have a positive impact on income distribution - due to the fact that a large share of total employment is informal and excluded from this benefit. At the same time, productivity levels are much lower than in most OECD countries, implying that the dynamics of growth and decent job creation have been weak.

In the Northwest quadrant, there are countries which have emphasized structural change over redistribution. The amount of social expenditure remains at very low levels (less than 9\% of GDP) in countries like Korea, Hong Kong and Singapore. The pattern of distribution that emerges from structural change in developing Asia is based on the rapid fall of underemployed workers in total employment, a growing demand of qualified workers, and high rates of economic growth that make compatible the growth of productivity and that of employment. On the other hand, some of these countries - in particular Korea - have acknowledged the need to move towards a more inclusive social system, curbing the rise in inequality observed in the 2000s. With this aim they have increased social expenditure (Elekdag, 2012). At variance with the few Latin American countries that made a similar move in the 2000s, this was accompanied in the case of Asia by fast productivity growth. Developing Asia, however, is far from homogeneous: Thailand and Philippines followed a pattern more similar to Latin America than to other Asian countries. They have adopted a path featuring low productivity growth and a significant increase in social expenditures as a percentage of GDP.

The next section looks in more detail the determinants of income distribution - firstly institutions and secondly the production structure.

\section{THE ROLE OF INSTITUTIONS}

Institutions shape growth and income distribution in two moments. Firstly, institutions affect market outcomes and define the rules of the game changing 
the relative power and behavior of the agents before and during the competitive process; and secondly, they also redefine ex post the income distribution produced by the market. Market distribution does not arise from the workings of a pure exchange economy, but is embedded in a very strong political economy vector ${ }^{4}$. It cannot be said that markets work first and then institutions redistribute; instead, political economy and institutions are at the core of market power and market outcomes in both rounds - ex ante and ex post the market processes.

The impact of redistribution on income distribution may be addressed by looking at income distribution before and after taxes and transfers, as shown in Table 1.

Table 1: Gini index after and before taxes and transferences

(In the late 2000s)

\begin{tabular}{lccc}
\hline & $\begin{array}{c}\text { Before Taxes and } \\
\text { Transferences }\end{array}$ & $\begin{array}{c}\text { After Taxes and } \\
\text { Transferences }\end{array}$ & $\begin{array}{c}\text { Percent } \\
\text { Variation }\end{array}$ \\
\hline Australia & 46.9 & 33.4 & -28.8 \\
Austria & 47.9 & 26.7 & -44.3 \\
Belgium & 47.8 & 26.2 & -45.2 \\
Canada & 44.7 & 32.0 & -28.4 \\
Czech Republic & 44.9 & 25.6 & -43.0 \\
Denmark & 42.9 & 25.2 & -41.3 \\
Estonia & 48.7 & 31.9 & -34.5 \\
Finland & 47.9 & 26.0 & -45.7 \\
France & 50.5 & 30.3 & -40.0 \\
Germany & 49.2 & 28.6 & -41.9 \\
Greece & 52.2 & 33.7 & -35.4 \\
Iceland & 39.3 & 24.4 & -37.9 \\
Ireland & 59.1 & 33.1 & -44.0 \\
Israel & 50.1 & 37.6 & -25.0 \\
Italy & 50.3 & 31.9 & -36.6 \\
Japan & 48.8 & 33.6 & -31.1 \\
Korea & 34.1 & 31.0 & -9.1 \\
Luxembourg & 46.4 & 27.0 & -41.8 \\
Netherlands & 42.4 & 28.8 & -32.1 \\
New Zealand & 45.4 & 31.7 & -41.1 \\
Norway & 42.3 & 24.9 & \\
\hline & & & \\
\hline
\end{tabular}

\footnotetext{
${ }^{4}$ The strength of labor unions, social legislation, policies of education and training, and the commitment of the monetary and fiscal policies with full employment, all of them have a strong influence on the distributive outcome of the market process.
} 


\begin{tabular}{llll}
\hline Poland & 46.8 & 30.5 & -34.8 \\
Portugal & 52.2 & 34.4 & -34.1 \\
Slovakia & 43.7 & 26.1 & -40.3 \\
Slovenia & 45.3 & 24.6 & -45.7 \\
Spain & 50.7 & 33.8 & -33.3 \\
Sweden & 44.1 & 26.9 & -39.0 \\
Switzerland & 37.2 & 29.8 & -19.9 \\
United Kingdom & 52.3 & 34.1 & -34.8 \\
United States & 49.9 & 38.0 & -23.8 \\
OECD Average & 46.8 & 30.1 & -35.4 \\
Argentina & 50.6 & 44.7 & -11.7 \\
Bolivia & 50.3 & 49.3 & -1.9 \\
Brazil & 60.0 & 54.1 & -9.8 \\
Mexico & 50.9 & 48.8 & -4.1 \\
Peru & 50.3 & 49.3 & -1.9 \\
Uruguay & 52.7 & 45.4 & -13.8 \\
Latin America Average & 52.8 & 49.4 & -6.3 \\
\hline
\end{tabular}

Sources: OECD and Lustig et al. (2014).

There are significant differences between the income distribution that emerges from market process and that effectively observed after taxes and transfers (see Table 1). An economy comprising marked cleavages across wages and profits could nevertheless show low levels of inequality. For if the political economy of the country is such that allows the government to tax firms and workers with the highest levels of income and then redistribute these taxes towards both workers with lower wages and the unemployed, then it is possible to have, at the same time, a high market-driven Gini index with a low Gini index after redistribution. However, there are limits to redistribution based on taxes and transfers. There is a strong correlation between the Gini index of income inequality before taxes and the same index after taxes (of about $60 \%$ in the sample of 36 countries presented in Table 1), which suggests that Gini indexes produced by market outcomes and that produced by direct redistribution are not completely detached. A well-known explanation is that the political economy that determines the intensity of redistribution is not independent of the production structure, but the discussion of this topic largely exceeds the objectives of this work.

The literature on the close links between political and economic power is very old and well established (for an interesting assessment see Bowles and Gintis, 1992) and yet cyclically rediscovered by the economic profession (see Acemoglu et al., 2013). As a mental exercise, compare two production structures, one complex and diversified (high KI) and the other one a polar structure with a few high productivity sectors (low KI). The polar structure will tend to concentrate both 
economic and political power. It is more difficult for the government to tax the rich and redistribute income in a country in which the elite is highly concentrated, controls a large share of total capital and natural resources, and which is therefore able to mobilize massive economic resources to lobby against laws and policies that contradict their interests. The wealthiest groups will use their economic power to enhance its political power and the other way round (i.e., they will use political power to consolidate oligopoly positions in the market). The mutual reinforcement between privileges in the economic system and influence in the political arena underlies the positive correlation between Gini before and after taxes and transfers. This is also why countries with a less diversified production structure tend to have more political instability and less consolidated democratic systems than countries with a more knowledge intensive production matrix. Inversely, it is more likely to find a larger number of powerful actors in a KI economic structure - each with her specific capabilities, economic resources, projects of investment and political influence. This would produce a polity which is less susceptible to the dominance of a tiny minority. The need of coordinating a large variety of valuable capabilities that must be put together to bring about competitiveness and growth creates an environment which is much more conducive to cooperation than an environment that confront the owners of natural resources with a destitute unskilled labor force. In the first case, negotiations among the various actors will be built upon the challenge of generating rents out of knowledge and innovation. In the second case, negotiation will focus on the redistribution of the rents derived from the property of natural resources. In the first case, the politics of productivity will go hand in hand with the politics of distribution; in the second case the economy revolves around a zero sum game driven almost exclusively by redistribution and conflict over a rent whose size is highly sensitive to international shocks. It is easy to make a parallel between these patterns of interaction between the production structure, income distribution and the political economy of productivity and redistribution and the low and high learning equilibrium illustrated in the matrix presented in fifth section.

Table 1 indicates that the importance of direct redistribution should not be underestimated: it has a strong impact on inequality, and differences among countries in the intensity of this mechanism are a crucial determinant of why inequality varies so widely in the international economy. In effect, the difference between Scandinavians and the rest of the developed countries (from instance, the UK) in terms of income distribution is largely due to the impact of direct redistribution through taxes and transfers. In several European countries, the Gini after taxes and transfers falls more than $40 \%$ (vg., Finland and Slovenia reduce the Gini in about 46\%). The average fall in Gini in the OECD countries is 35\%, much higher than the best performer in Latin American (which is Uruguay, where the Gini falls 12\%).

Korea is a particular case in the sense that there is little redistribution through taxes and transfers, but nevertheless shows low levels of inequality. Sustained growth through many decades reducing underemployment seems to have played a more important part in reducing inequality in Korea than in other economies. 
The very high levels of investment - and the ensuing process of structural change — implied steady growth and high demand for skilled labor, whose counterpart was an efficient education system. Small and medium enterprises are integrated to the export chain values in Korea, in such a way that segmentation and asymmetries in capabilities across firms tend to be lower than those observed in Latin America. For all these factors Korea stands in a peculiar position, being a country in which direct redistribution is rather low but which nevertheless does not display the so high levels of inequality observed in Latin America.

\section{THE PRODUCTION STRUCTURE AND INCOME DISTRIBUTION}

The production structure plays a central role in income distribution, as reflected in the large body of literature on the Kuznets curve - which is mostly about structural change (see for instance Higgins and Williamson, 1999). The production structure of an economy can be defined by two attributes, diversification and knowledge intensity (DKI). An economy has a higher DKI as compared to other economy when it presents a large set of capabilities and in particular of knowledgeintensive capabilities. The rationale for defining the production structure in this way lies on the importance of DKI for productivity and economic growth.

Firstly, productivity and productivity growth tends to be higher in sectors with higher knowledge-intensity. Learning and technical change are localized and closely related to experience in production (learning by doing), while at the same time there are complementarities between skills and (tangible and intangible) assets in different sectors (intra- and inter-industry externalities). For this reason the presence of knowledge-intensive sectors in the production structure carries strong implications for innovation, learning and hence productivity growth. This is shown in Graphs 2 and 3 which plots the ECLAC Knowledge Intensity Index ${ }^{5}$ (EKII) and the Index of Economic Complexity (ECI of Haussmann, Hidalgo et al., 2011), respectively, against relative productivity for a sample of 67 countries in 2012. A high correlation between DKI (proxied by EKII and ECI) and productivity is visible, although of course no direction of causality can be established between DKI and productivity from these graphs.

Secondly, countries with a higher DKI will be more competitive in domestic and external markets. They will be more able to keep or expand market shares in the international economy. As a result growth will be more persistent and stable in economies with a high DKI than in economies which are strongly dependent on exports of few commodities or natural resources, whose effective demand depends on the vagaries of the "commodity lottery". A less diversified, less knowledge-intensive economy (lower

\footnotetext{
${ }^{5}$ ECLAC Knowledge Intensity Index is defined as the simple average between R\&D expenditure as a share of GDP, patents per million of inhabitants and exports of high technology over the total exports. Each variable is escalated between 0 and 1 .
} 
DKI) will face more difficulties to sustain long run growth; it may experience phases of spasmodic growth reflecting cycles in price and demand for commodities (the commodity lottery), but these phases are bound to be short-lived.

Graph 2:

EKII and relative labor productivity, 2002 (Dollars 2005)

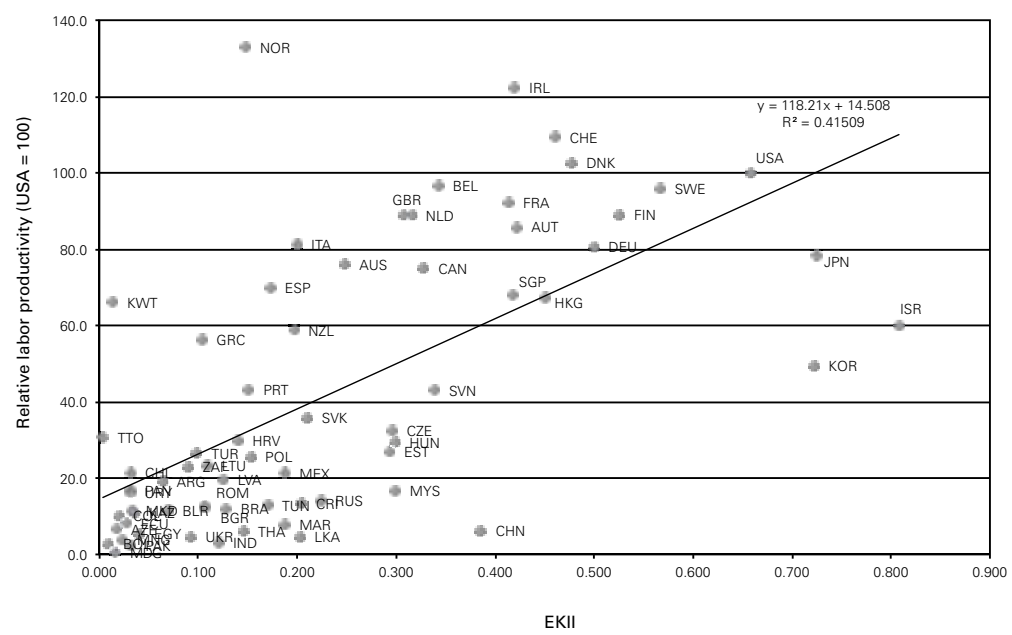

Sources: World Development Indicators, World Bank; COMTRADE; Laborstat, ILO; USPTO; UNESCO.

Graph 3:

Relative labor productivity and ECI (Dollars 2005)

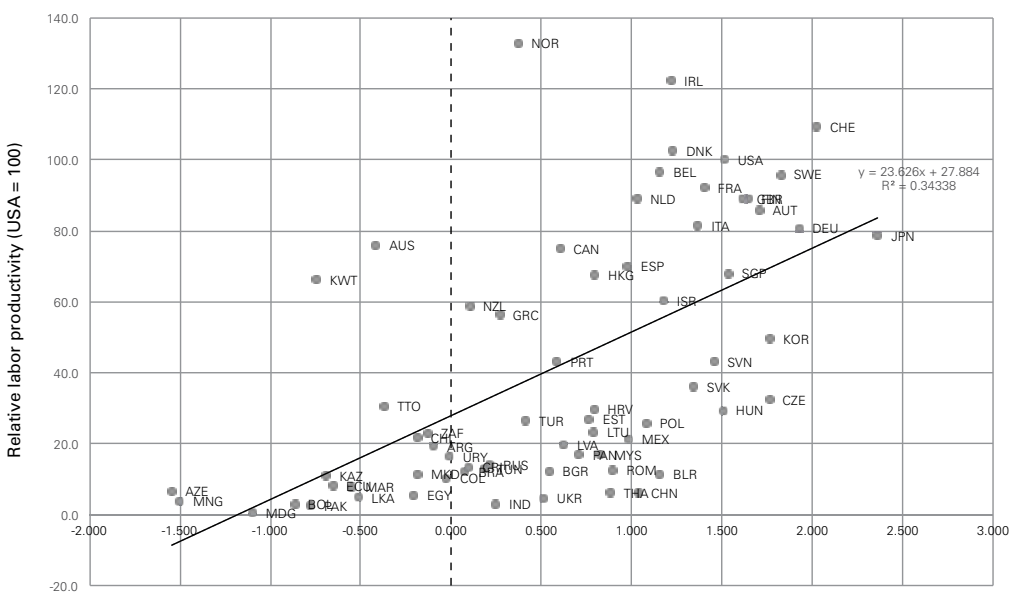

$\mathrm{ECl}$

Sources: World Development Indicators, World Bank; Laborstat, ILO; Atlas of Complexity economics. 
DKI has a positive impact on the functional distribution of income (labor share) in two ways: (i) by reducing the share of the unemployed and of those employed in low-productivity (mostly informal) jobs in total employment (whose wages are extremely low, not rarely at the level of mere subsistence in developing economies); (ii) by keeping the rate of employment at a higher and more stable level, thereby strengthening the bargaining power of labor in wage negotiations. Income distribution within workers, however, may not improve out of structural change as the latter creates strata of workers with different wage levels. The Gini index might indeed worsen as a result of structural change if the labor market is highly segmented between the "modern" and "traditional" sectors and a growing schism emerges among groups of workers. The institutional setting then plays a crucial role in shaping the impact of structural change on workers' inequality. The existence of mechanisms allowing for spreading the benefits accruing to workers in the leading sector to the rest of the labor force is crucial for preventing the Gini index to increase along with the wage share. The inverse is also possible: regressive structural change leads to a fall in the Gini index (reflecting higher income equality within workers, as high productivity jobs are lost), while the wage share falls out of lower and more instable levels of employment.

Firms that compete in high-tech sectors hire a larger share of educated labor than the average, compete in markets where price competitiveness is less important than innovation and quality, and enjoy higher markup levels (Reinert, 1995). They also pay higher wages and capture monopolistic rents. This form a link between asymmetries in productivity / technology and asymmetries in income, by which higher levels of heterogeneity (asymmetry) in productivity favor inequality in income distribution. Moreover, the presence of increasing returns produces different paths of productivity growth, which heighten initial differences in wages and profits. While heterogeneity in productivity exists in all types of economies ${ }^{6}$, asymmetries tend to be higher in enclave economies than in economies where DKI is higher (Pinto, 1970, 1976; Infante and Sunkel, 2009; Lavopa, 2011; Soares, 2013). As mentioned, these differences in productivity and income may or may not be corrected through taxes and transfers.

Wages, productivity and income distribution are frequently associated with the level and distribution of human capital, which is perceived as a factor of production that workers can accumulate by allocating more time to education and /or training. However, the demand and supply of capabilities are not independent of the production structure. The demand for skilled labor increases with the variety and sophistication of the capabilities used in the production processes, and so does the probability with which educated workers find a job. In addition, learning takes place not only in schools and universities, but on the production process. A higher invest-

\footnotetext{
${ }^{6}$ The creation of heterogeneity is the very object of innovation, which is aimed at producing (more or less transitory) advantages in productivity and quality (Cimoli and Dosi, 1995; Dosi et al., 2008, 2010a, 2010b).
} 
ment in education would have little effect when structural change is absent. Graph 4 shows that a rising public expenditure in education did not have a strong impact on productivity levels in Latin America. Education and structural change should be addressed as complementary, co-evolving variables in the economic system.

Graph 4: Education and labor productivity in Latin America $(1990=100)$

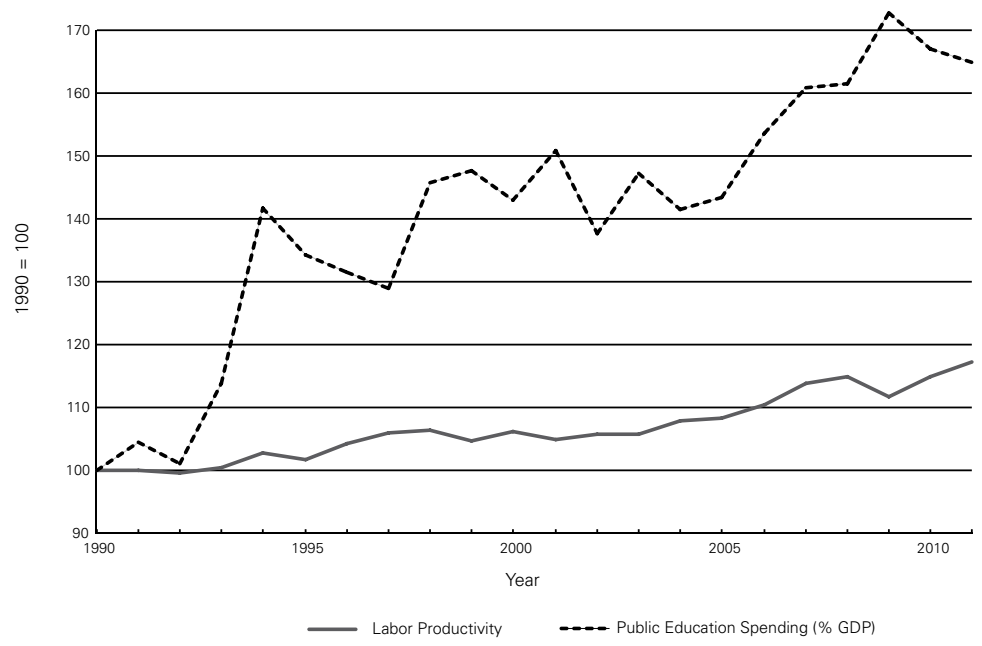

Sources: World Development Indicators, World Bank; CEPALSTAT; Laborstat, ILO.

The pattern that emerges from the set of incentives to invest in education and from the learning processes implicit in the simple structures of many developing countries can be represented as an "equilibrium trap" of low education, low demand and supply of qualified labor, leading to slow growth in the long run.

\section{THE POLITICAL ECONOMY OF UNSTABLE EQUILIBRIUM}

Table 2 summarizes the previous discussion in a matrix combining different production structures and institutional settings.

Table 2: Patterns of growth and income distribution: a typology

\begin{tabular}{|c|c|c|}
\hline \multirow{2}{*}{ Production structure } & \multicolumn{2}{|c|}{ Institutions } \\
\hline & Weak & Strong \\
\hline Knowledge intensive & $\begin{array}{l}\text { A Sustainable growth, } \\
\text { intermediate inequality }\end{array}$ & $\begin{array}{c}\text { B Sustainable growth } \\
\text { and equality }\end{array}$ \\
\hline Simple & $\begin{array}{l}\text { C Unsustainable growth, } \\
\text { high inequality }\end{array}$ & $\begin{array}{l}\text { D Unsustainable growth, } \\
\text { intermediate inequality }\end{array}$ \\
\hline
\end{tabular}


Points $\mathrm{B}$ and $\mathrm{C}$ in the matrix are two opposite equilibrium cases, one which reproduces slow structural change, slow learning and substantial inequality, and the other that sustains a pattern of rapid productivity growth with high equality. Boxes $\mathrm{A}$ and $\mathrm{D}$ cannot be considered stable. In box A, higher levels of productivity and employment strengthen the perception that the country should pay more attention to welfare and the protection of those left behind, particularly when political democracy is consolidated. The politics in the countries of box A creates incentives to raise social expenditure, as has been increasingly the case, for instance, in Korea. In Box $\mathrm{D}$, slow productivity growth and high levels of inequality stresses the political system. In particular, a fiscal expansion to promote equality in a context in which the lack of competitiveness heightens the external constraint is short lived. The spiral among wages, inflation and the real exchange rate would give rise to an external crisis or persistent high inflation, curbing investment - producing a "stop and go" type of dynamics. The bargaining power of workers and the pro-distribution coalition in government would be unable to overcome the challenge of economic instability. Unless a broad consensus around the politics of productivity could be generated, there is a chance that political and economic turbulences bring the country back to box C.

There is an important difference in terms of the interaction between political and economic variables in the unstable boxes $\mathrm{A}$ and $\mathrm{D}$. Transition from box A to $\mathrm{B}$ is more likely and could be more easily attained than the transition from $\mathrm{D}$ to $\mathrm{B}$. In the first case, the domestic market expands and welfare expenditures curb inequality without compromising stability or raising negative expectations of an external crisis. Economic expansion strengthens the political support of pro-equality policies. Politic and economic stability reinforce each other. In the second case, on the other hand, the political and economic dynamics move in opposite directions. Economic difficulties weaken the pro-distribution coalition. Political instability in turn undermines the efforts for structural change and distribution. The economy moves closer to negative-sum games, in such a way the direct redistribution might be eventually abandoned. Moving from D to B becomes a highly unlikely or even unattainable outcome. The more likely result from this political economy is that the economy settles in the low-growth, high-inequality path represented by box $\mathrm{C}$.

\section{A simple model of structural change and redistribution}

This section presents a simple model which illuminates the forces behind the different growth and income distribution paths discussed above. Income distribution is determined by the production structure and the institutional setting. Two kinds of institutions are highlighted, those that affect the rate of economic growth and those that affect transfers from high income to low income agents.

\section{GROWTH AND THE PRODUCTION STRUCTURE}

The point of departure of the analysis is the Keynesian idea that, in open economies, economic growth depends in the long run on the ratio between the country's income elasticity of exports $\left(\varepsilon^{x}\right)$ and its income elasticity of imports $\left(\varepsilon^{m}\right)$, 
where $\varepsilon \equiv\left(\varepsilon^{x} / \varepsilon^{x}\right)$ is the income elasticity ratio. The higher is e, the higher the share of the country in the distribution of global effective demand, i.e., the higher is its market share in the domestic and international economy. The income elasticity ratio gives the rate of growth rate at which the country can grow without facing mounting disequilibria in the external front - The BOP-constrained growth rate, widely used in Keynesian growth models (Thirlwall, 1979, 2011; Setterfield, 2009; Blecker, 2013) and in the structuralist tradition in development theory (Rodriguez, 1977, 2007; Cimoli and Porcile, 2011, 2014).

The income elasticity ratio in turn is a function of the country's production structure: what the country produces matters for growth. If the production structure of country A is highly specialized in goods which show very low income elasticity of demand, then a rise in international demand would fail to stimulate growth in country A. Inversely, if country A raises domestic effective demand (through, for instance, an Keynesian expansionary fiscal policy), the result will be a higher external deficit and a "stop and go" growth dynamics.

Formally:

1) $y=\varepsilon g$

In equation (1), $\mathrm{y}$ is the equilibrium (BOP constrained) rate of economic growth, $\mathrm{e}$ is the income elasticity ratio and $\mathrm{g}$ is the rate of growth of the international economy.

Specialization is driven by leads and lags in technological capabilities (Montobbio and Rampa, 2005; Reinert, 1995; Verspagen, 1993): countries that are closer to the technological frontier are competitive in a more diversified set of goods which also entail higher technological intensity. These countries have the necessary capabilities to react swiftly to new competitive challenges and keep their position in the most dynamic segments of world markets. The evolution of the technology gap between a developing economy and an economy on the technological frontier depends on the efforts made by the developing economy to absorb, adapt and improve foreign technology. The intensity of these efforts can be captured by the concept of the National System of Innovation (NSI) or National System of Learning (see Freeman, 1995; Metcalfe, 2001; Narula, 2004). The strength of the NSI - the set of institutions, firms and (public and private) agencies which invest, promote and coordinate the processes of innovation and diffusion of technology, defining the market and nonmarket incentives for learning, along with investments in education and training - determines the velocity with which the developing economy is able to learn from the technological leaders and reduce the technology gap - or at least prevent the gap from moving up. Public investments and policies for supporting innovation and diffusion of technology are central to the NSI.

Assume that the government collects and spends the share $x$ of total GDP; the budget is in equilibrium and the tax burden corresponds to the share of public expending in total demand. Taxes are paid by the firms on a lump sum basis. The government allocates its resources in two alternative uses: income redistribution or strengthening the NSI. The tax share which is used with a purely redistribution 
objective (transfers) is $\delta$, while the share of GDP allocated to the NSI is $(1-\delta)$. The values of $x$ and $\delta$ depend on political economy variables, which are assumed exogenous.

The impact of public investment in the NSI (i.e., $x(1-\delta))$ in the production structure can be summarized as follows:

2) $\varepsilon=\varepsilon[x(1-\delta)]$

Equation (2) states that the income elasticity ratio is a function of public investment in the NSI. Clearly, public investment is just part of the story of the NSI, whose strength also depends on private investments. Nevertheless the role of public investment is crucial (Mazzucato, 2013; Mazzucato et al., 2015), particularly in developing economies, due to the crowding in effect as it complements and attracts private investments.

Combining (1) and (2), the equilibrium rate of economic growth can be written as:

3) $y=\varepsilon[x(1-\delta)] g$

Equation (3) points out that growth depends on the production structure which in turn is a function of the share of GDP invested in the NSI, along with the rate of growth of the rest of the world. This equation captures the role of effective demand (through the income elasticity ratio) and the role of technology-driven structural change (through the influence of the NSI in fostering technical change and changing the production pattern).

\section{Employment and productivity}

Income distribution $(D)$ depends on the wage share in total income and on transfers from the government to correct inequality both between capital and labor and within labor itself:

$$
\text { 4) } D=D(\omega, \delta)
$$

The wage share emerges from negotiations between firms and unions in the labor market. The bargaining power of unions depends on the employment rate, $E$ $=N / L$, where $N$ is total employment and $L$ is total labor supply. Therefore, the wage share in total income depends positively of the employment rate, as suggested below:

$$
\text { 5) } \omega=\omega(E)
$$

The growth of the employment rate $e=\dot{E} / E$ responds positively to a rise in economic growth $(y)$ and negatively to a rise in labor productivity growth $(\pi)(e=$ 
$y-\pi$ ). Using equation (3) to obtain growth in equilibrium, then the growth of the employment rate is:

6) $e=\psi[\varepsilon[x(1-\delta)] g-\pi]$

Labor productivity growth follows a pure Kaldor-Verdoorn dynamics, rising when the employment level rises:

7) $\pi=\pi(E)$

Combining equations (5) and (6) it is possible to find the equilibrium rate of employment as a function of the share of the GDP which is invested by the government in the NSI. For the sake of simplicity, it will be assumed a linear specification for equations (3) and (7). This renders the following linear differential equation:

8) $e=\psi[a g+b[x(1-\delta)] g-\alpha E]$

In equation (8), the income elasticity ratio depends on $a$ (which reflects competitiveness not related to public investment in the NSI) and $b$ (which reflects the impact on competitiveness of investing in the NSI). The last term of the equation (8) points out that productivity growth rises with the employment rate, which is the pro-cyclical effect related to Kaldor-Verdoorn, whose intensity is captured by the parameter $\alpha$.

In equilibrium $e=0$ and therefore:

9) $E^{*}=\frac{[a+b x(1-\delta)] g}{\alpha}$

The equilibrium is stable since $\partial e / \partial E<0$. For a given total tax share $x$ in GDP, a rise in transfers reduces public investment in the NSI, which in turn compromises growth and leads to a lower equilibrium employment rate. Higher transfers therefore reduce the intensity of structural change and long run growth ${ }^{7}$.

\section{Income distribution}

In order to analyze the dynamics of income distribution, equation (4) can be specified as:

10) $D=\omega(E) h \delta x$

Income distribution equals the wage share times a factor that depends on the

\footnotetext{
7 Some transfers may reduce inequality while at the same time increasing productivity and competitiveness. For instance, cash transfers to poor families may reduce under nutrition that hampers the learning ability of children in poverty, or they may improve the productivity of workers less affected by health problems.
} 
share of resources $(x \delta)$ directed at improving income distribution, along with the efficiency $(b)$ with which the government uses these resources. Using (9) in (10):

$$
\text { 11) } D=\frac{[a+b x(1-\delta)] g}{\alpha} h x \delta
$$

Equation (11) suggests that income distribution is a nonlinear function of the share of GDP allocated to foster equality. Figure 1 shows that there is critical level of transfers, $\delta_{c}$, after which income distribution worsens when $\delta$ increases. The reason for this is competition of resources between policies aimed at raising equality and policies aimed at raising competitiveness and structural change. A use of public investment too skewed in favor of direct redistribution may lead to sluggish structural change, less employment growth and a weakening of the labor market and labor bargaining power.

Figure 1: Income inequality, redistribution policy and the NSI

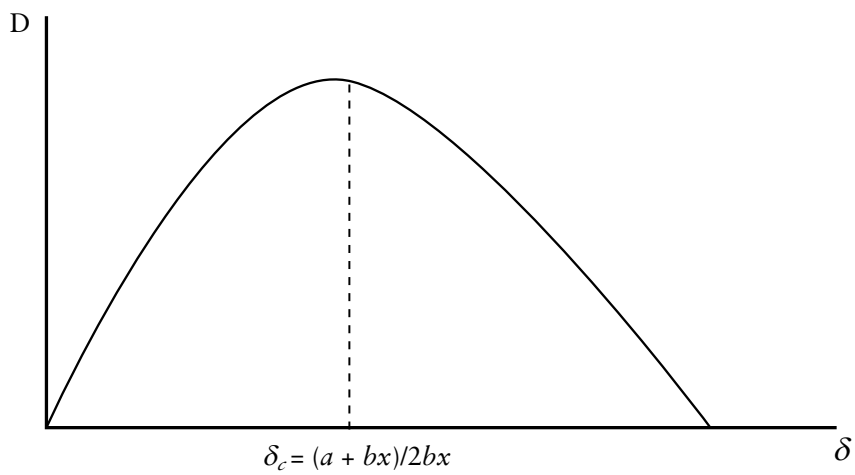

The critical level of redistributive spending $\delta_{c}$ (which produces the highest equality) is not fixed, but it is a function of the production structure. In effect, the highest level of equality is attained when $\delta_{c}=(a+b x) / 2 b x$. Recalling that $a$ is the autonomous component of the income elasticity ratio, when this component is high there will be more room for pure redistributive policies. An economy whose competitiveness is very low will find more barriers (due to the rapid emergence of the external constraint) to advance in reducing inequality trough taxes and transfers than a more diversified economy. On the other hand, a higher $b$ (which gives the impact on growth of investing in the NSI) reduces the critical level of redistributive spending. A higher $b$ implies a stronger impact of R\&D on growth and employment, and hence a larger role for growth in income distribution. While the case of a high a may represent the case of mature economies with a production structure which is already highly knowledge-intensive (say Denmark or Sweden), the case of a high $b$ represents economies in which growth and structural change are the key to sustain employment and wages (say Korea or Taiwan).

For the same critical level of redistribution efforts, income distribution improves when the rate of growth of the international economy $(g)$ is higher. This is 
not surprising: a higher $g$ stimulates growth in the domestic economy and brings about a rise in the level of employment in equilibrium. Such a rise in employment strengthens the bargaining power of workers, leading to a higher wage share out of negotiations in the labor market.

The experience of the countries of Latin America that benefited from the commodity boom of 2004-2014 — where formal employment and wages increased substantially - are an example of this case.

The model must not be read as suggesting that there is little room for redistributive policies in developing economies whose production structure is weak. First, there is no need to assume that $x$ is fixed. In most developing economies $x$ is extremely low (indeed, it is less than half of the figures observed in developed economies) and there is a large space for a balanced budget expansion. Second, the redistribution effect of tax and transfers (captured by $h$ ) may be substantially improved. In most developing economies $b$ is much lower than in developed economies, and this implies that more equality can be attained by reshaping the tax and transfer system. By the judicious use of fiscal policies aimed at raising the parameters $x$ and $h$, and industrial and technological policies aimed at fostering innovation and structural change, it would be possible to move further towards a sizable increase in sustainable income distribution in Latin America.

\section{CONCLUDING REMARKS}

There have been significant advances in income distribution in most Latin American countries since 2004. The forces that explain such advances are two: a change in international conditions that eased the external constraint, allowing for faster growth and the reduction of unemployment and informality; and a rise in transfers and social expenditures giving access to basic services (such as health and education) to a larger segment of the population. In spite of these positive trends, there are still two important concerns for policy-makers in the region.

The first is that the improvement of the past decade was unable to alter the position of Latin American as the most unequal region in the world. The second is the sustainability of these improvements, in particular in the context of a less favorable international scenario. While productivity remained stagnant, the share of social expenditure as a percentage of GDP increased substantially, particularly in Argentina, Brazil and Uruguay. If world demand slows down, the current deficit in current account that experiences the region will worsen. If this triggers a rise in interest rates and the adoption of more austere fiscal policy, growth and employment recede. It is likely that social expenditure will suffer in this case, and so will at least part of the advances achieved in the social front.

The politics of productivity cannot be delinked from the politics of redistribution. The adoption of active industrial policies is a necessary condition for keeping the momentum of the recent move towards increasing social expenditure in Latin America. The clock of fiscal austerity is ticking faster as world demand losses mo- 
mentum and tensions in the external front become more pressing in Latin America. The crucial question is whether an acceleration of productivity growth would come in time to at least cushion the negative impact of a period of fiscal austerity on employment and income distribution. It is urgent to advance industrial policy within the policy agenda, which has been, and continuous to be, a crucial missing factor in the Latin American efforts to build more equalitarian and dynamic economies.

\section{REFERENCES}

Acemoglu, D.; Naidu, S.; Restrepo. P. And Robinson, J. (2013) "Democracy, redistribution and inequality”, NBER Working Paper Series, N. 19746, December.

Bertola, L. and Ocampo, J.A. (2012) The Economic Development of Latin America Since Independence. Oxford: Oxford University Press.

Blecker, R.A. (2013) "Long-run growth in open economies: export-led cumulative causation or a balance-of-payments constraint?” In Harcourt, G. and Kriesler, P., eds., Oxford Handbook of Post-Keynesian Economics, 390-414, Oxford: Oxford University Press.

Bowles, S. and Gintis, H. (1991) "Power and Wealth in a Competitive Capitalist Economy", Philosophy and Public Affairs 21 (4), pp. 324-353.

Cimoli, M. and Dosi, G. (1995) “Technological Paradigms, Patterns of Learning and Development: An Introductory Roadmap” Journal of Evolutionary Economics, 5(3), p. 243-68.

Cimoli, M. and Porcile, G. (2011) "Global growth and international cooperation: a structuralist perspective”, Cambridge Journal of Economics, vol. 35, no. 2, 383-400

Cimoli, M. and Porcile, G. (2014) "Technology, structural change and BOP-constrained growth: a structuralist toolbox", Cambridge Journal of Economics 38 (1): 215-237.

Dosi, G., Faillo M. and Marengo, L. (2008) “Organizational Capabilities, Patterns of Knowledge Accumulation and Governance Structures in Business Firms: An Introduction”, Organization Studies, vol.29, pp. 1165-1185.

Dosi, S. Lechevalier, A. Secchi (2010a) "Introduction: Interfirm heterogeneity? Nature, sources and consequences for industrial dynamics”, Industrial and Corporate Change, 19(6): 1867-1890.

Dosi, G., Grazzi, M., Tomasi, C. and Zeli, A. (2010b) “Turbulence underneath the big calm? Exploring the micro-evidence behind the flat trend in manufacturing productivity in Italy", LEM Working paper, January.

ECLAC (2014) "Compacts for Equality: Towards a Sustainable Future”, Santiago: ECLAC.

ECLAC (2016) "Horizons 2030: Equality at the centre of sustainable development”, Santiago: ECLAC. Elekdag, S. (2012) "Social Expenditure in Korea: Can it Foster Sustainable and Inclusive Growth", IMF Working Paper, Asia and Pacific Department, WP 12/250, October 2012.

Freeman, C. (1995) The national system of innovation in historical perspective, Cambridge Journal of Economics, vol. 19, no. 1, 5-24

Hausman, R; Hildalgo, C. el al. (2011) “The Atlas of Economic Complexity”, Center for International Development at Harvard University

Higgins, M., \& Williamson, J. G. (1999) "Explaining inequality the world round: Cohort size, Kuznets curves and openness,” NBER Working Paper No. 7224.

Infante, R, and Sunkel, O. (2009) "Chile: Hacia un desarrollo inclusivo”, Revista de la CEPAL, 98:135154.

Lavopa, A. (2011) "The Impact of Sectoral Heterogeneities in Economic Growth and Catching up: Empirical Evidence for Latin American Manufacturing Industries”, UNI-MERIT Working paper Series, 2011-075.

Lustig, N., Pessino, N. \& Scott, J. (2014) “The impact of Taxes and Social Spending on Inequality and 
Poverty in Argentina, Bolivia, Brazil, Mexico, Peru and Uruguay”, Public Finance Review, May, vol. 42 no. 3 287-303.

Mazzucato, M. (2013) “The Entrepreneurial State: Debunking the Public vs. Private Myth in Risk and Innovation", London, Anthem.

Mariana Mazzucato \& Mario Cimoli \& Giovanni Dosi \& Joseph Stiglitz \& Michael Landesmann \& Mario Pianta \& Rainer Walz \& Tim Page, (2015) "Which industrial policy does Europe need?," Intereconomics: Review of European Economic Policy, Springer, vol. 50(3), pages 120-155, May.

Metcalfe (2001) "Institutions and Progress", Industrial and Corporate Change, 10 (3): 561-86.

Montobbio, F.; Rampa, F. (2005) "The impact of technology and structural change on export performance in nine developing countries”, World Development, Elsevier, 33(4): 527-547.

Narula, R. (2004) "Understanding absorptive capacities in an innovation systems context: consequences for economic and employment growth", DRUID Working Paper no. 04-02, December.

Pinto, A (1970) "Naturaleza e implicaciones de la 'heterogeneidad estructural' de la América Latina", El Trimestre Económico, vol. 37(1), no. 145, México, D.F., Fondo de Cultura Económica, enero-marzo.

Pinto, A. (1976) "Heterogeneidad estructural y modelo de desarrollo reciente de la América Latina". Inflación: raíces estructurales, México, D. F., Fondo de Cultura Económica.

Reinert, E. S. (1995) “Competitiveness and its predecessors - a 500-year cross-national perspective", Structural Change and Economic Dynamics, vol. 6, 23-42

Rodrik, D. \& McMillan, M. (2011) “Globalization, structural change and productivity growth”, NBER Working Papers 17143, National Bureau of Economic Research, Inc.

Rodríguez, O. (1977) “Sobre la concepción del sistema centro-periferia”, Revista de la CEPAL, first semester

Rodríguez, O. (2007) El Estructuralismo Latinoamericano. México: Siglo XXI

Setterfield, M. (2009) "Neoclassical growth theory and heterodox growth theory: opportunities for and obstacles to greater engagement”, Trinity College Department of Economics, Working Paper 09-1, December.

Soares, S. (2013) "Can changes in structural heterogeneity explain the fall in earnings inequality? An analysis for Brazil”. PGNET Conference, University of Copenhaguen, 17-18 October.

Thirlwall, A. P. (1979) "The balance of payments constraint as an explanation of international growth rate differences", Banca Nazionale di Lavoro, vol. 128, 45-53

Thirlwall, A. (2011). "Balance of payments constrained growth models: history and overview”, Discussion Paper no. 1111, University of Kent School of Economics

Verspagen, B. (1993) Uneven Growth between Interdependent Economies. Avebury: Aldershot. 